\title{
INDEMNIZACIÓN DE DAÑOS POR INFRACCIÓN DE DEBERES CONYUGALES
}

\author{
COMPENSATION OF DAMAGES FOR BREACH OF \\ SPOUSAL DUTIES
}

\author{
CAROLA PAZ RIVAS VARGAS* \\ Ministra de Corte de Apelaciones \\ Poder Judicial \\ Concepción - Chile
}

\section{RESUMEN}

El presente trabajo plantea la controversia sobre la procedencia de la indemnización civil por los perjuicios causados por la infracción de deberes conyugales, con especial análisis de los casos de adulterio o infidelidad, materia que en los últimos años ha sido ampliamente debatida en la doctrina comparada, tratando de establecer la necesaria vinculación del derecho de daños con el derecho de familia, abandonando las posturas sobre la independencia y especialidad de las leyes de familia, dado el ambiente donde ella debe ser aplicada. En nuestro país el debate ha nacido después de la entrada en vigencia de la ley de divorcio y la aparente insuficiencia de la acción por compensación económica, para resolver acerca de los perjuicios que surgen por causa del matrimonio y la infracción de las obligaciones que la ley impone a los cónyuges.

Palabras clave: Indemnización, matrimonio, obligaciones, adulterio.

\footnotetext{
* Abogada, Licenciada en Ciencias Jurídicas y Sociales de la Pontificia Universidad Católica de Chile; Magíster en Derecho Privado de la Universidad de Concepción. Magistrada de la República de Chile. Correo electrónico crivas@pjud.cl. Archivo recibido el 7 de mayo de 2017 y aceptado para su publicación el 2 de agosto de 2017.
} 


\section{ABSTRACT}

The present work raises the controversy about the origin of the civil compensation by the damages caused by the infringement of conjugal duties, with a special analysis of adultery and infidelity cases. In the last few years, this subject has been widely debated in the comparative doctrine trying to establish the necessary bonding between right to damages with family laws, discarding the postures about the independence and speciality of family laws, given the environment where it has to be applied. In our country the debate was born after the validity of the divorce law and the apparent insufficiency of the economic compensation, to resolve the damages that arise because of marriage and the violation of the obligations that the law imposes on the spouses.

Keywords: Compensation, marriage, obligations, adultery.

\section{INTRODUCCIÓN}

Es necesario partir este trabajo estableciendo que, al margen de la definición legal del contrato de matrimonio y de sus efectos en la esfera de lo estrictamente jurídico, es cierto que dicha unión se crea y sostiene en los sentimientos de amor y cariño de las partes y se desenvuelve en distintos ámbitos, como en la convivencia, la sexualidad, el proyecto de vida en común, entre otros aspectos, sumándose también intereses patrimoniales que incluyen la adquisición y administración de los bienes.

Este particular contenido del contrato de matrimonio, que también se refleja en los deberes que legalmente se imponen en el Código Civil, informa las conductas que deben adoptar los cónyuges. El problema se plantea entonces cuando existe un comportamiento anormal o ajeno a sus obligaciones de parte de alguno de los contrayentes y es ahí cuando nos enfrentamos a una parte que no adopta una conducta que le impone el matrimonio configurado, el incumplimiento de un deber conyugal; entonces, la pregunta que surge es si aquél puede causar un daño y si éste es susceptible de ser indemnizado.

Mientras en la doctrina comparada, la relación entre el derecho de daños con el derecho de familia se viene discutiendo hace años, en nuestro país el debate ha tenido que nacer luego de la instalación del divorcio vincular y la insuficiencia de la ley de matrimonio civil, a través del ejercicio de la acción por compensación económica, para resolver acerca de los perjuicios que surgen por causa del matrimonio y la infracción de las obligaciones que la ley impone 
a los cónyuges: "Solo muy tímidamente, a diferencia de lo que sucede en otros países-incluso cercanos cultural y geográficamente-como Argentina, Francia y España, se está abriendo paso en nuestra jurisprudencia la discusión por la procedencia de la responsabilidad civil por ilícitos cometidos en el ámbito del Derecho de Familia". ${ }^{1}$

En efecto, las profundas modificaciones que se han venido produciendo en el ámbito del derecho de familia y el desarrollo que ha venido presentando el derecho de daños en base al principio de su reparación integral, han llevado a preguntarse si los daños injustamente producidos en el seno de la familia se solucionan con las normas de la responsabilidad civil del derecho privado, o si, por el contrario, las reglas del derecho de familia son autosuficientes para reparar los perjuicios causados en el ámbito familiar.

En este sentido, cabe preguntarse si es posible reparar los daños y perjuicios producido por la falta de reconocimiento de un hijo y el abandono sufrido por éste o el que se causa a un progenitor cuando por años se le impide el contacto con sus hijos; pero más aún, en materia de deberes conyugales, si es factible afirmar la procedencia de la indemnización por el daño producido por violencia doméstica o por la adquisición de alguna enfermedad venérea a causa de la infidelidad del cónyuge o plantearse si el sólo adulterio igualmente admite dicha reparación.

En este trabajo se enfrentan dos posiciones. Por una parte, si cada una de las infracciones a los deberes que impone el matrimonio dan lugar a indemnización en caso de producir daño, lo que en palabras de la jueza argentina Graciela Medina se resume en: "si se puede dañar sin reparar, se puede lastimar faltando a los deberes morales impuestos por el matrimonio sin que sea necesario indemnizar a quien ha sufrido el daño causado con dolo o culpa, en aras de privilegiar la libertad personal sobre la responsabilidad por daños señalando simplemente que son deberes morales"; 2 o al contrario, si la naturaleza de los deberes conyugales permite considerarlos sólo deberes morales, sin acción para hacerlos exigibles, por lo que se debe estar a los propios remedios que establece la ley de familia y dejarlos al margen del derecho de daños, ello por cuanto, en palabras del profesor Mauricio Tapia, "las familias se constituyen por vínculos de cooperación y solidaridad, que se debilitarían si se abre la puerta a las demandas de indemnización; el derecho

1 Corral Talciani, Hernán, "La Incipiente Jurisprudencia Chilena sobre Daños en Familia", Revista de Derecho de Familia, 2014, ํ 4, pp. 51-60.

2 Medina, Graciela, "Daños en el Derecho de Familia en el Código Civil y Comercial Unificado", Revista de Derecho de Familia y Sucesiones (Argentina), 2015, № 5 (Sept.), 07-09-2015, Cita: IJLXXX-322; disponible en línea: http://www.gracielamedina.com/assets/Uploads/medina.pdf . 
de las familias responde a principios que le son propios, donde no tendrían espacio estas figuras patrimoniales". ${ }^{3}$

2. TRATAMIENTO DE LA RESPONSABILIDAD CIVIL EN EL ÁMBITO DE LAS RELACIONES FAMILIARES EN NUESTRO ORDENAMIENTO JURÍDICO

Existen en nuestro Código Civil normas que permiten la aplicación de la responsabilidad civil en el ámbito de las relaciones familiares en su aspecto exclusivamente patrimonial. Algunos ejemplos son:

a) Si el marido administra fraudulentamente la sociedad conyugal (aplicable también al régimen de participación en los gananciales), la ley da derecho a pedir la separación judicial de bienes, conforme al artículo 155.

b) En la administración que hace el padre respecto de los bienes de los hijos en el ejercicio de la patria potestad. La ley a pesar de consagrar expresamente la responsabilidad del padre hacia el hijo hasta la culpa leve (art. 256), frente al actuar doloso o gravemente culposo (con habitualidad) del padre o madre que tiene la administración, la sanción que le señala es la privación de dicha administración, la que pasará al otro padre o a un curador de bienes.

La situación es completamente diferente, por ejemplo, cuando la administración de los bienes del hijo la tiene un tercero (tutor o curador), aquí rige plenamente el derecho a la reparación "por la negligencia del guardador en proceder al inventario y por toda falta grave que se le pueda imputar en él, podrá ser removido de la tutela o curaduría como sospechoso, y será condenado al resarcimiento de toda pérdida o daño que de ello hubiere resultado al pupilo, de la manera que dispone en el artículo 423" (art. 378 inciso $2^{\circ}$ ).

c) También en materia de filiación se otorga acción de indemnización de perjuicios a quien ejerza una acción de filiación de mala fe o con el propósito de lesionar la honra de la persona (art. 197).

No debe olvidarse, por otra parte, lo dispuesto en el artículo 489 del Código Penal que absuelve de responsabilidad penal a los cónyuges por los hurtos y defraudaciones, pero expresamente indica que quedarán sujetos a la responsabilidad civil que emane de los referidos delitos. Dicha excusa

\footnotetext{
3 Tapia Rodríguez, Mauricio, “Aproximación Crítica a la Indemnización de Perjuicios por Incumplimiento de Deberes Conyugales”, en Vidal Olivares, Á; Severin Fuster, G; Mejías Alonzo, C. (Coords.) Estudios de Derecho civil X, Thompson Reuters, Santiago, 2015, pp. 231-248.
} 
absolutoria, en palabras del profesor Etcheberry, responde a razones de conveniencia social y para mantener la armonía familiar. ${ }^{4}$

En relación a los deberes personales conyugales establecidos en el Libro I, Título VI, denominado "Obligaciones y Derechos entre los cónyuges" del Código Civil, se contemplan soluciones particulares en relación a cada incumplimiento distintas a las indemnizaciones pecuniarias propias del derecho de daños. Es así que la infracción al deber de fidelidad contemplado en el artículo 131, facultará al cónyuge perjudicado a solicitar el divorcio conforme la causal del artículo $54 \mathrm{~N}^{\circ} 2$ de la Ley de Matrimonio Civil o la separación judicial que contempla su artículo 26. Si la mujer además está casada bajo el régimen de sociedad conyugal puede pedir la separación judicial de bienes (art. 155 inc. $2^{\circ}$ del C.C.). Las mismas consecuencias acarrea la vulneración del deber de respeto recíproco y del deber de socorro. En el caso de la obligación de alimentos, propia del deber de socorro, el cónyuge incumplidor puede verse enfrentado a una demanda de alimentos y en otro escenario, configura una causal para rechazar el divorcio solicitado.

Como se aprecia y salvo lo relativo a los alimentos, cada una de las infracciones a los deberes conyugales contempla una sanción propia, pero ninguna establece expresamente una acción judicial que permita exigirlas o hacer efectivo su cumplimiento. Parece obvio que por respeto y reconocimiento al libre albedrío del ser humano, no puede el derecho generar exigencias como la de vivir en el hogar común, protegerse, amarse, ayudarse mutuamente en alguna actividad o simplemente, la abstención del adulterio. Sobre el particular el profesor René Ramos Pazos indica que: "El Derecho o es por sí mismo incapaz de provocar mediante la coerción la observancia de dichos preceptos, o cree más conveniente confiar su observancia (...) a otras fuerzas que actúan en el ambiente social". ${ }^{5}$

La imposibilidad de acción de cumplimiento se expresa con mayor claridad en el deber de cohabitación, también llamado débito sexual, donde resultaría infructuoso para el derecho establecer medios de coerción para el cumplimiento de este deber, resultando más adecuado dejarlo al sentido ético de los cónyuges. Sin perjuicio de ello, su incumplimiento podría traer aparejado la revocación de ciertas donaciones que por causa del matrimonio se hubieren hecho, si éste no se hubiere consumado (art. 1792).

4 Etcheberry Orthusteguy, Alfredo, Derecho Penal, Parte General, Editorial Jurídica de Chile, Santiago, 1999, Vol. II, Reimpresión de la $3^{\text {a }}$ edición, p. 12.

5 Ramos Pazos, René, Derecho de Familia, Editorial Jurídica de Chile, Santiago, 2010, $7^{\text {a }}$ ed., T. I, p. 143. 


\section{LA COMPENSACIÓN ECONÓMICA Y SU RELACIÓN CON LOS DAÑOS EN EL MATRIMONIO}

La Ley $N^{\circ}$ 19.947, vigente desde el año 2004, entre otras modificaciones, incorporó el divorcio vincular por cese de convivencia o por causal imputable a uno de los cónyuges, regulando los efectos económicos de la ruptura matrimonial en base a la protección al cónyuge más débil, estableciéndolo como uno de los principios que debe guiar al juez en los procesos de familia. Esta normativa también contempla sanciones específicas para determinados casos donde existe infracción a los deberes conyugales, considerándolo causal de divorcio por culpa en el artículo $54 \mathrm{y}$, para el caso de separación judicial por culpa, dispone el cese de los derechos hereditarios al cónyuge que hubiera dado lugar a ella, como lo indica el inciso final del artículo 35.

Ahora bien, la compensación económica constituye una solución específica que esta ley contempla para el término del matrimonio. Se vincula a la responsabilidad civil porque con ella se pretende reparar ("compensar") algunos perjuicios ("menoscabo") que aparecen con ocasión del término del vínculo matrimonial; sin embargo, describiendo su naturaleza jurídica, la doctrina nacional le ha negado un carácter puramente indemnizatorio, por cuanto en este caso no concurre el elemento daño de la forma como lo describe la responsabilidad civil. Sería entonces una forma de resarcimiento de un cierto daño, es decir, de una cierta pérdida producida por el hecho de haber dedicado el esfuerzo de la vida matrimonial al cuidado de los hijos o a las tareas del hogar y que ha impedido, por lo mismo, una vida de trabajo con resultado económico y que permita así enfrentar la vida futura una vez producida la extinción del matrimonio. ${ }^{6}$ Así, la suma que se concede al cónyuge demandante sólo otorga una satisfacción pecuniaria que pretende aplacar la desmejorada situación económica en que queda el cónyuge más débil.

También se esgrime que la compensación económica participaría de la naturaleza jurídica de las denominadas "indemnizaciones por sacrificio", que son compensaciones que las leyes atribuyen, en muchos casos, a determinados sujetos, como consecuencia de una pérdida, ablación o limitación forzosa de derechos subjetivos o como recompensa parcial del sacrificio que se exige a los titulares. Se trataría de las denominadas indemnizaciones por afectación lícita de derechos, similar a las indemnizaciones que se pagan en caso de

\footnotetext{
6 Domínguez Águila, Ramón: "La compensación económica en la nueva legislación de matrimonio civil”, Actualidad Jurídica (UDD), 2007, № 15, pp. 83-92.
} 
expropiación o por la imposición de servidumbres legales. ${ }^{7}$

En resumen, la compensación económica es un derecho patrimonial de naturaleza familiar y que, por lo tanto, tiene naturaleza jurídica propia, sin ser posible relacionarla directamente a alguna categoría preexistente del Derecho civil patrimonial. Siendo así, la compensación económica es un derecho que tiene por objeto una prestación de dar una suma de dinero o de unas especies dadas en pago que permitan al cónyuge beneficiario rehacer su vida futura y separada y alcanzar, en la medida de lo razonable, un estatus económico autónomo, que perdió con el matrimonio o que nunca alcanzó. La compensación tiene una función de impulsar al cónyuge a que sea autosuficiente, a que se inserte o reinserte en el mercado laboral y que así obtenga su propio sustento sin depender en el futuro de quien fuera su cónyuge. Detrás de la compensación económica está la responsabilidad de cada uno de los cónyuges de ser autosuficientes económicamente. A la compensación económica le repugna la pasividad del cónyuge beneficiario de compensación tras el divorcio o nulidad. ${ }^{8}$

Como se evidencia, las tesis alimenticias e indemnizatorias son insuficientes para explicar los particulares caracteres de la institución en comento, pudiendo concluirse que la compensación económica no es más que una prestación pecuniaria que procura dar una solución concreta a un problema específico, cual es la eventual posición desmejorada en que puede quedar el cónyuge más débil al momento del divorcio. Así, no sería más que una obligación impuesta por la ley, que se concede en los eventos previstos por ella, de contenido patrimonial y que, fundada en la equidad, tiene por finalidad entregarle herramientas al cónyuge más débil para que pueda reiniciar dignamente su vida separada. ${ }^{9}$

Considerando, entonces, que la compensación económica no tiene por objeto resarcir todo eventual perjuicio que con motivo u ocasión del divorcio pudiere producirse, puede llegar a concluirse, sin lugar a dudas, que ella es compatible con la responsabilidad civil. ${ }^{10}$ Se trata de una institución que no

7 Corral Talciani, Hernán, "La compensación económica en el divorcio y la nulidad matrimonial", Revista Chilena de Derecho, 2007, vol. 34 No 1, pp. 23 - 40, disponible en línea: http://www.scielo. cl/scielo.php?script=sci_arttext\&pid=S0718-34372007000100003 .

8 Vidal Olivares, Álvaro, "La noción de menoscabo en la compensación económica por ruptura matrimonial", Revista de Derecho P. Universidad Católica de Valparaíso, 2008, Vol. XXXI (2do sem.), pp. 289-321.

9 Céspedes Muñoz, Carlos; Vargas A., David, “Acerca de la naturaleza jurídica de la compensación económica. La situación en Chile y en España”, Revista Chilena de Derecho, 2008, Vol. 35, No 3, pp. 439-462.

${ }^{10}$ Domínguez Hidalgo, Carmen, "El convenio regulador y la compensación económica: una visión en conjunto", en Universidad de los Andes (Editor), Cuadernos de extensión jurídica, 2005, №.11, pp. 120- 
tiene por finalidad reparar los daños que la infracción de los deberes conyugales pudiere provocar ni tampoco reparar el daño moral que un cónyuge pudiere experimentar por la declaración misma de divorcio y ello por cuanto no es consecuencia de ningún hecho ilícito.

Sobre esta materia es conveniente traer a colación la sentencia de la Corte de Apelaciones de Santiago ${ }^{11}$ que resuelve la acción deducida por la cónyuge quien, mediante la compensación económica, pretendía la indemnización de los malos tratos que padeció durante la convivencia conyugal, los cuales, si bien se tuvieron por acreditados al acogerse la demanda de divorcio por culpa, no eran posibles ser reparados en la forma pedida, ya que según se resolvió en su considerando quinto: "no es la compensación económica una institución creada para reparar este tipo de perjuicio y puede la actora, si asi lo estima, perseguir la responsabilidad del demandado de acuerdo a las normas generales del Código Civil, en la sede y de acuerdo al procedimiento correspondiente, pero lo que no puede pretender es que el supuesto perjuicio que le habrían irrogado los malos tratos del demandado le sean indemnizados por la vía del artículo 61 de la Ley de Matrimonio Civil".

En otras palabras, los sentenciadores descartaron que la compensación económica sea el medio idóneo para reclamar la indemnización de los daños y perjuicios que uno de los cónyuges haya padecido a consecuencia de los malos tratos ejercidos por el otro, pero agrega, dejando abierta la puerta, que los reclamos de esta naturaleza deben hacerse de acuerdo a las normas generales del Código Civil, esto es, las normas de la responsabilidad civil y no otras. ${ }^{12}$

\section{DISCUSIÓN DOGMÁTICA RESPECTO DE LA PROCEDENCIA DE APLICAR LA RESPONSABILIDAD CIVIL POR INFRACCIONES DE DEBERES MATRIMONIALES}

\subsection{Posturas a favor}

En países como España y Argentina la discusión sobre la relación entre el Derecho de Familia y el Derecho de Daños lleva años de desarrollo progresivo,

121; TURNER SAELZER, Susan, "Sentencia sobre requisitos de procedencia y finalidad de la compensación económica (Corte de Apelaciones de Valdivia)", Revista de Derecho (Valdivia), 2006, Vol. 19, № 2, pp. 272-273.

${ }^{11}$ Corte de Apelaciones de Santiago, 4 de noviembre de 2010, Rol No 890-2010.

${ }^{12}$ En el mismo sentido, Corte de Apelaciones de Rancagua, 29 de octubre de 2007, Rol No 672-2007, donde resolviendo una demanda reconvencional de divorcio por culpa e indemnización de perjuicios expresó en su considerando tercero que "cabe señalar que este rubro no lo contempla la Ley 19.947...". 
concluyéndose en forma casi unánime sobre la admisión de la responsabilidad civil en la infracción de deberes conyugales sin que para ello se haya necesitado la modificación de los Códigos Civiles pertinentes. ${ }^{13-14}$

Al igual que en nuestro país, los autores que se manifiestan a favor de la procedencia de la indemnización de perjuicios, consideran que el derecho de familia no es un conjunto de normas absolutamente cerrado y de aplicación exclusiva y excluyente, sino que debe abrirse al derecho de daños cuando éstos efectivamente se produzcan y proceda su reparación. Se argumenta, asimismo, que las sanciones específicas establecidas en el ordenamiento jurídico en la esfera civil y penal no agotan los remedios puestos para el amparo del cónyuge en cuanto persona, para el cual la familia constituye un ámbito de autorrealización de los derechos irrenunciables como la salud, la integridad personal, el honor y todos los demás derechos personalísimos. El hecho de que existan sanciones propias en el derecho de familia a determinadas conductas no es razón suficiente para excluir una eventual responsabilidad civil (cuando concurren los elementos de ésta), pues la separación o divorcio no puede conceptuarse como la sola sanción frente al incumplimiento, sino que como una forma de resolver jurídicamente las crisis matrimoniales. ${ }^{15}$

En este sentido, el tradicional principio de especialidad del derecho de familia y el tratamiento separado que siempre se le ha otorgado respecto del resto del ordenamiento jurídico -justificado por los principios que lo informan- no tiene en cuenta las profundas transformaciones que ha experimentado; es así que ha de considerarse que la evolución de la responsabilidad civil por hecho ilícito, la ha convertido en un instrumento cada vez más eficaz para la protección de las situaciones jurídicas de naturaleza personal, lo que constituye una de las razones

\footnotetext{
${ }^{13}$ Algarra Prats, Esther, "Incumplimiento de deberes conyugales y Responsabilidad Civil", en Moreno Martínez, Juan A. (Coord.), La responsabilidad Civil en las Relaciones Familiares, Dykinson, Madrid, 2012; Marín GarCía de LeONARDo, Teresa, "Remedios Indemnizatorios en el Ámbito de las Relaciones Conyugales", Revista Aranzadi de Derecho Patrimonial (España), 2006, N 17 ('Daños en el derecho de Familia').

${ }^{14}$ Medina, cit. (n. 2); también en Medina, Graciela; Roveda, Eduardo G., Derecho de Familia, Abeledo Perrot, Buenos Aires, 2016, 1024 pp.

${ }^{15}$ Novales Alquezar, Aranzazu, "Responsabilidades Especiales, ¿Debieran haber en el Derecho Matrimonial Mecanismos reparatorios?", en AA.VV., Regímenes especiales de responsabilidad civil, Cuadernos de Análisis Jurídicos, Colección Derecho Privado IV, Ediciones Universidad Diego Portales, Santiago, 2008, pp. 119-150. Dicho trabajo proviene del Proyecto de investigación "Análisis de la responsabilidad civil en el Derecho de Familia Comparado. Las relaciones personales entre los cónyuges"; del grupo de Derecho Privado y Europeo de la Universidad Pública de Navarra, cuya Ed. responsable fue la Dra. Elsa Sabater Bayle. En el texto citado se menciona entre los autores que adhieren a la primera posición a Teresa Marín García de Leonardo, Gabriel García Cantero, José De Verda y Beamonte; Algarra Prats (n. 13), también menciona a los autores Chaparro y Matamoros; Sainz Cantero, Pérez Vallejo y en Chile, Vargas Aravena.
} 
que se esgrimen con más fuerza para compatibilizar y admitir su incursión al interior del Derecho de Familia. Al decir de doña Graciela Medina: "Es que las relaciones familiares tienen un especial contenido solidario y es en el ámbito familiar donde el individuo se puede desarrollar y al mismo tiempo es en ese ámbito íntimo donde más se puede dañar al otro, es por eso que no puede quedar sin indemnizar los daños causados por quien tenía la obligación de ayudar a desarrollar al otro y en su lugar produce un daño cuya gravedad debe ser apreciada justamente por haber sido provocada en el entorno familiar". ${ }^{16}$

En esta postura, la noción de daño injusto ha de ser entendida partiendo de la base de reconocer que en el derecho de familia hay obligaciones cuyo incumplimiento lesiona intereses que son merecedores de tutela, puesto que no debe ser restringida solo a una dimensión patrimonial sino que debe abarcar otras esferas del desarrollo de la persona, como es su matrimonio o sus hijos.

En el mismo sentido, la profesora Jimena Valenzuela del Valle expresa que: "Los deberes y derechos emanados del matrimonio son derechos y obligaciones de pleno valor jurídico, con sanciones jurídicas y no meramente morales. Las sanciones civiles especiales asociadas al incumplimiento grave de obligaciones matrimoniales no excluyen otras sanciones, especialmente la indemnización de daños no cubiertos por ellas, especialmente la indemnización del daño moral'. ${ }^{17}$

Por consiguiente, cabe concluir que la moderna concepción de familia permite, en principio, derribar reglas y postulados que durante tanto tiempo han impedido y obstaculizado la aplicación de las normas generales de la responsabilidad civil. Existen daños que se producen en el seno de las relaciones familiares cuya reparación no entra dentro de las normas específicas que el derecho de familia dedica a estos casos. ${ }^{18}$ Sin perjuicio de ello, la autora Teresa Marín García de Leonardo suaviza su postura al señalar que en el ámbito de derecho de familia no se pude aceptar sin más la obligación de reparar todo daño, puesto que pueden existir aquellos que no son de suyo indemnizables y para ello habrá de tenerse en cuenta el juicio de desvalor del resultado producido y si entra dentro de los esquemas de la responsabilidad civil. En definitiva, se parte de que la simple violación de un deber conyugal no puede conducir por sí mismo a una declaración de responsabilidad, porque habrá que

\footnotetext{
${ }^{16}$ Medina, cit. (n. 2).

17 Valenzuela del Valle, Jimena, "Responsabilidad Civil por el incumplimiento de obligaciones matrimoniales y por el ejercicio abusivo del divorcio unilateral. Un estudio de su admisibilidad en Chile", Revista de Derecho Universidad Católica del Norte, 2012, № 1, Año 19, pp. 241-269.

${ }^{18}$ Marín García de Leonardo, cit. (n. 13), pp. 171 ss.
} 
tener en cuenta si la conducta es dolosa o gravemente culposa, si hay nexo causal y fundamentalmente el daño producido.

Según los autores antes señalados, y a modo de resumen, la circunstancia que el legislador no haya previsto la posibilidad de reparar los daños consecuencia del incumplimiento de los deberes conyugales no puede ser un argumento en contra de la posible reparación de daños y perjuicios, porque tampoco existe norma alguna que lo prohíba. No se trata de introducir criterios de culpabilidad o inocencia en la separación y en el divorcio sino de determinar si cuando existe un daño debe ser indemnizado porque lesiona derechos e intereses del cónyuge, es decir, la injusticia de un concreto daño indemnizable con independencia de que éste pueda, si quiere, optar por la separación o el divorcio. Ambas soluciones caben en procedimientos distintos y la no admisión del resarcimiento argumentando que ello sería volver a un sistema de separación o divorcio-sanción lo único que se consigue es que una persona que sufre un daño no disponga de la protección suficiente y que el autor del daño -por mucho que sea familiar de la víctima- quede impune.

\subsection{Posturas en contra}

La opinión contraria considera, entre otros argumentos, que las soluciones a los problemas familiares deben buscarse dentro del derecho de familia, teniendo en cuenta su regulación actual y aplicando aquellas consecuencias que sus normas prevean expresamente; ${ }^{19}$ ello por cuanto dicho estatuto jurídico ha establecido sanciones específicas para el incumplimiento de sus deberes, por lo que gravar a los familiares con la indemnización, envolvería una doble sanción: "Si los deberes familiares no son susceptibles de cumplimiento forzado en naturaleza, no pueden ser objeto de una indemnización de perjuicios; existen molestias en la convivencia familiar que deben ser toleradas y permitir el ejercicio indiscriminado de la acción de perjuicios abriría la puerta para que casos de bagatela y sin mayor sustento jurídico se comenzarán a ventilar, provocando una sobrecarga innecesaria del sistema judicial, que desincentivaría el matrimonio, producto de que los futuros contrayentes podrían verse expuestos no sólo al divorcio sino también a acciones de indemnización". ${ }^{20}$

Se afirma que en las familias deben primar vínculos de solidaridad y altruismo, que se verían mermados ante la posibilidad de interponer reclamos

\footnotetext{
${ }^{19}$ Algarra Prats, cit. (n. 13). En la opinión contraria menciona a Roca Trias, Llamas Pombo, Martin Casals, González Beilfuss y otros, con denominación de cada una de las obras de dichos autores.

${ }^{20}$ Tapia Rodríguez, cit. (n. 3).
} 
judiciales y si bien es probable que al interior de las relaciones de familia se produzcan daños, a tales hechos no corresponde aplicar el estatuto de responsabilidad civil puesto que su judicialización traería como consecuencia el debilitamiento de la institución familiar. Entre otros argumentos en contra se mencionan también el desincentivo al matrimonio; la indebida intromisión en el libre ejercicio de los padres respecto del derecho a la educación de los hijos; la incongruencia con los principios que rigen el Derecho de Familia como el interés superior del niño y la protección del cónyuge más débil, que no puede compararse con otras realidades como las del ámbito de los bienes y las obligaciones civiles o comerciales y el eventual abuso de los derechos indemnizatorios que se podrían reconocer a los miembros de una familia. ${ }^{21}$

Si bien el estatuto de responsabilidad civil que regula nuestro Código Civil contempla un amplio ámbito de aplicación sin exclusión de las relaciones de familia, ello no puede ser utilizado como argumento para indemnizar el daño por las infracciones de los deberes matrimoniales, puesto que, a primera vista, la ausencia de alguna prohibición específica y el particular tratamiento en cuanto a las sanciones frente al incumplimiento de las obligaciones en dicho ámbito, parece indicar que la intención del legislador es impedir la aplicación de las normas comunes de responsabilidad civil en los casos de infracción de los deberes personales que nacen de las relaciones de familia y, especialmente, en los deberes que surgen del matrimonio, distintos del deber de socorro o alimentos.

En este sentido el profesor Mauricio Tapia señala: "El derecho no puede obligar a las personas a quererse, a seguir queriéndose o quererse de una determinada manera. El derecho sólo cuenta con instrumentos para asegurar el cumplimiento de obligaciones familiares patrimoniales (pensión de alimentos por ejemplo), que responden a principios y reglas del derecho patrimonial, pues son obligaciones de esa naturaleza. Si no se provee amor a un cónyuge (o se prodiga excesivo amor a un tercero), el derecho no puede hacer nada (salvo constatar legalmente la ruptura matrimonial si ello es solicitado por uno o ambos cónyuges)...".22

Para los profesores Rodrigo Barcia y José M. Rivera, el problema de fondo es la libertad y la diferenciación entre derecho y moral. En esta materia es donde precisamente se aprecian los peligros de la excesiva intervención de los jueces en la moral de los individuos (corriente que se ha denominado

\footnotetext{
${ }^{21}$ Los referidos argumentos están profusamente explicados en la Memoria de Prueba de CoRnEJo García, María Gloria, "Particularidades de la responsabilidad civil extracontractual en el Derecho de Familia", Universidad de Chile, Memoria de Prueba de Pregrado, Santiago, 2012; disponible en línea: http://repositorio.uchile.cl/bitstream/handle/2250/112811/de-cornejo_m.pdf?sequence=1 .

${ }^{22}$ TAPIA Rodríguez, cit. (n. 3).
} 
como neo-constitucionalismo). Esta corriente de pensamiento podría llevar a que los jueces estén facultados para poder inmiscuirse en el fuero interno de las personas, dando lugar a una prueba en que se ventilan los aspectos más íntimos y difíciles de resolver del ser humano. ${ }^{23}$

Es preciso señalar que muchos de los autores que adscriben a esta postura no excluyen totalmente la reparación de los daños provenientes de ilícitos en que incurran los cónyuges en perjuicio del otro. Es así como se acepta la procedencia de la indemnización, específicamente, cuando existe vulneración a la integridad física o psíquica del cónyuge, como lo son los casos de violencia intrafamiliar, o se vulneran otros derechos de la personalidad reconocidos en el Código Civil, como la honra. Desde este punto de vista, los reclamos judiciales sólo serían aceptables si se dan circunstancias particulares que justifiquen su ejercicio, como por ejemplo, que se haya cometido un ilícito que afecte la convivencia familiar.

En esta línea de argumentación, no es posible excluir a priori la aplicación de normas resarcitorias en el ámbito de la familia cuando los daños tienen como origen un hecho ilícito, por lo que, de concurrir los restantes presupuestos legales, procederá su reparación: "El punto clave en este debate es determinar cuándo el daño causado por el cónyuge que viola un deber conyugal puede ser calificado como daño injusto. No hay ninguna inmunidad conyugal que excluya el resarcimiento entre cónyuges, sino la necesidad de distinguir si hay una violación de los deberes conyugales que pertenece al derecho de familia y que debe resolverse con sus propias reglas o si el incumplimiento tiene una relevancia que permite acudir al instituto de la responsabilidad aquiliana, porque a la violación del deber conyugal se suma la violación del respeto a situaciones subjetivas relevantes: desde esta perspectiva, la violación del deber conyugal representa la ocasión para la lesión no del cónyuge en cuanto tal, sino del cónyuge en cuanto persona por encima de todo". ${ }^{24}$

Con la ayuda de esta tesis doctrinaria podemos argumentar que la simple infracción de los deberes conyugales no legitima la declaración de responsabilidad, sino que aquélla requiere necesariamente la producción de un daño que provenga de un hecho particularmente grave e ilícito: "Sólo procede el resarcimiento en los casos en los que la conducta-particularmente grave-del familiar no sólo haya violado una de las obligaciones familiares,

\footnotetext{
${ }^{23}$ Barcia Lehmann, Rodrigo; Rivera Restrepo, José M., “En qué casos el incumplimiento de deberes del matrimonio genera responsabilidad civil?", Revista Ius et Praxis (Universidad de Talca), 2015, Año 21, No 2, pp. 19-60.

${ }^{24}$ Algarra Prats, cit. (n. 13).
} 
sino provocado, al mismo tiempo, la lesión de un interés que el ordenamiento no puede tolerar soporte la víctima, sino que sea cargado sobre el autor del hecho, en cuanto que resulte lesivo de intereses jurídicamente relevantes, al margen de su calificación formal". ${ }^{25}$

En este mismo sentido, refiriéndose a la reparación del daño causado con ocasión del divorcio, el autor Francisco Herane Vives sostiene que: “... en principio, no se vislumbra ninguna buena razón para impedir, a priori, una posible indemnización por el incumplimiento de los deberes matrimoniales. Ahora bien, lo anterior no significa que todo daño sufrido por el divorcio dé origen, por su sola existencia, a la procedencia de una reparación, sino que deben configurarse los presupuestos exigidos por la responsabilidad extracontractual: una conducta antijurídica, factor de atribución: dolo o culpa, un nexo causal y, por supuesto, un daño"; a lo que agrega: "Concuerdo con la mayoría de la doctrina que se ha expresado al respecto, en cuanto a que los daños derivados del divorcio vincular por incumplimiento de los deberes matrimoniales, en la medida que se reúnan los requisitos señalados precedentemente, no constituyen responsabilidad contractual sino que más bien obedecen al ámbito de lo extracontractual, con fundamento en el carácter jurídico del matrimonio". ${ }^{26}$

También lo hace el profesor Gonzalo Severín Fuster, en cuanto afirma: "No será admisible una indemnización de perjuicios entre los cónyuges por los hechos constitutivos de divorcio sanción sino cuando se trate de ofensas o atentados a la vida o la integridad física y síquica. Con esto lo que hacemos es dejar abierta la posibilidad de obtener una reparación en los casos en que ha existido algún tipo de violencia intrafamiliar, a la vez que cerramos, por ejemplo, para el adulterio, el alcoholismo, la conducta homosexual, etc. Desde luego, si con ocasión de algunos de estos hechos se produce un hecho ilícito, entonces la responsabilidad civil es ampliamente aplicable". ${ }^{27}$

\footnotetext{
${ }^{25}$ González Cazorla, Fabián, "Incumplimiento de deberes conyugales y acciones indemnizatorias: Un análisis sobre su procedencia", Derecho y Justicia 2014, № 4, consultada en línea: https://www. academia.edu/19067168/Incumplimiento_de_deberes_conyugales_y_acciones_indemnizatorias._Un_ an $\% \mathrm{C} 3 \% \mathrm{~A} 1$ lisis sobre su procedencia

${ }^{26}$ Herane Vives, Francisco, "Reparación por incumplimiento de los deberes matrimoniales", en Corral T., H; Rodríguez P., M. S. (Editores), Estudios de Derecho Civil II, LexisNexis, Santiago, 2007, pp. 181-193; también en AA.VV., Estudios de Derecho Civil, Familia y Derecho Sucesorio, Abeledo Perrot-Thomson Reuters, Santiago, 2015, T. V., pp. 105 y ss.

${ }^{27}$ SeVERín Fuster, Gonzalo, "Indemnización entre cónyuges por los daños causados con ocasión del divorcio", en AA.VV., Estudios de Derecho Civil, Familia y Derecho Sucesorio, Abeledo PerrotThomson Reuters, Santiago, 2015, T. V, pp. 165 y ss.
} 
5. POSTURAS RESPECTO DE CADA DEBER MATRIMONIAL, ESPECIALMENTE PARA EL CASO DE ADULTERIO

El artículo 131 del Código Civil señala: "Los cónyuges están obligados a guardarse fe, a socorrerse y ayudarse mutuamente en todas las circunstancias de la vida. El marido y la mujer se deben respeto y protección recíprocos". A su turno, el artículo 133 señala: "Ambos cónyuges tienen el derecho y el deber de vivir en el hogar común, salvo que a alguno de ellos le asista razones graves para no hacerlo". Continúa el artículo 136 con el siguiente tenor: "Los cónyuges serán obligados a suministrarse los auxilios que necesiten para sus acciones o defensas judiciales...".

Es así que la subsistencia de un matrimonio requiere del cumplimiento de cada uno de los deberes señalados y, precisamente, el artículo 54 de la Ley de Matrimonio Civil contempla el divorcio por falta imputable a uno de los cónyuges, cuando incurre en actos que constituyen violación grave de los deberes y obligaciones que les impone el matrimonio o de los deberes y obligaciones para con los hijos, que torne intolerable la vida en común. Los incumplimientos específicos a cada uno de los deberes conyugales se pueden reconocer en cada una de las causales que se contempla para el divorcio por culpa del otro cónyuge, entre ellas, los atentados contra la vida o malos tratamientos graves contra la integridad física o psíquica del cónyuge o de alguno de los hijos; la transgresión grave y reiterada de los deberes de convivencia, socorro y fidelidad propios del matrimonio incluido el abandono continuo o reiterado del hogar común.

\subsection{En cuanto al deber de socorro}

Este se traduce en la ayuda económica y en su caso el pago de alimentos. En este sentido, como ya se dijo, es el Derecho de Familia el que contempla los remedios necesarios para exigir su cumplimiento y sancionar su vulneración a través de las acciones pertinentes y los apremios frente al incumplidor.

\subsection{En cuanto al deber de respeto y ayuda mutua}

Este contiene un aspecto económico -ya desarrollado precedentementey también un aspecto referido al respeto de los derechos fundamentales del otro cónyuge. En este sentido el abanico de situaciones que deben respetarse se extienden desde la ideología moral, religiosa o política, el ámbito de intimidad del matrimonio hasta la prohibición de malos tratos físicos o psicológicos.

Ya se indicó en el capítulo anterior, que resulta pacífico en la doctrina 
la procedencia de la indemnización de perjuicios por daños patrimoniales y morales cuando han existido atentados a la integridad física o psíquica de alguno de los cónyuges cometidos por el otro, incluyendo la afectación de derechos personales como la honra. Pero, lo cierto es que no es correcto el análisis de dicha responsabilidad a alero del estatuto del Derecho de Familia, por cuanto ella está cubierta por las normas de la responsabilidad civil extracontractual, ya que se trata de un acto ilícito donde es indiferente la existencia o no de un vínculo matrimonial, de ahí que este tipo de infracciones no merecen ser estudiadas como una infracción específica de los deberes conyugales.

De esta manera, los actos de violencia intrafamiliar además de tener un remedio en el Derecho Penal sancionatorio y en el Derecho de Familia como causal de divorcio, admite la indemnización civil por los daños causados bajo el estatuto general de la responsabilidad civil extracontractual. Sobre el particular, en sentencia de la Corte de Apelaciones de la Serena ${ }^{28}$ se acogió la acción indemnizatoria presentada por la mujer en contra de su ex cónyuge después de haber obtenido a su favor el divorcio por culpa por los malos tratos inferidos durante el matrimonio, fundada en que si bien es discutible que la indemnización de perjuicios en el ámbito matrimonial sea aplicable para todas las causales de divorcio por culpa contempladas en el artículo 54 de la Ley de Matrimonio Civil, ya que "habría que analizar el caso concreto, con todas sus circunstancias", de lo que "no existe duda alguna, es que tal indemnización resulta del todo procedente cuando el motivo que dé lugar al divorcio afecta a la persona del otro cónyuge, independientemente si estaban o no unidos por el lazo matrimonial, como lo es, el atentado contra la vida o malos tratamientos graves contra la integridad física o psíquica del cónyuge víctima, cuyo es el caso de autos" (considerando decimocuarto).

En otras palabras, el tribunal de segunda instancia puso el acento en los daños causados por la lesión de la integridad física o psíquica de la víctima, más que en la existencia del vínculo matrimonial, sin perjuicio que los hechos que permitieron el acogimiento de la acción fueron establecidos en el juicio de divorcio, donde éste se acoge por los malos tratos inferidos a la demandante. Por cierto, se da por sentado que es posible pedir indemnización por responsabilidad civil por hechos que serían delitos o cuasidelitos civiles, prescindiendo de la relación conyugal o familiar que los liga. Así, un acto de violencia intrafamiliar que causa daño corporal o psicológico puede hacer surgir

${ }^{28}$ Corte de Apelaciones de La Serena, 3 de abril de 2014, Rol (I. Corte) N ${ }^{\circ}$ 507-2013; proveniente de sentencia del Tercer Juzgado de Letras de La Serena, "Pinto Carmona, Zunilda del Carmen con Rojas Núñez, Víctor Hugo", Rol C-3492-2010. 
responsabilidad civil, sin que pueda alegarse que se trató del incumplimiento de un deber de protección de carácter familiar.

Esta distinción es nuevamente remarcada en sentencia de la Corte Suprema de 30 de diciembre de 2014 (Rol No 10.622-14), que en su considerando sexto refiere que no se aprecia razón jurídica alguna que permita excluir la aplicación de los artículos 2314 y 2329 del Código Civil, por cuanto la obligación de indemnizar que el fallo impone al demandado no se basa en el mero incumplimiento de los deberes que el matrimonio impone a los cónyuges, sino en la configuración de todos y cada uno de los elementos de la responsabilidad extracontractual, cuales son: una conducta antijurídica, cometida por un sujeto capaz, la culpa del autor, la existencia del daño y el nexo o relación de causalidad entre dicho obrar y el daño provocado, aspectos que el fallo de primer grado analiza y da por establecidos en sus considerandos decimonoveno a vigesimosexto, último motivo donde concluye que: "De la prueba rendida en autos, analizada en esta sentencia se tiene por acreditado que el daño producido a la demandante, esto es, el daño emocional que se manifiesta por un síndrome ansioso depresivo, es el resultado natural de la conducta antijurídica e imputable al demandado, esto es, del abuso sicológico de parte de éste, lo que ha podido comprobarse en autos, dándose por establecida la relación de causalidad entre los malos tratos sicológicos y el diagnostico siquiátrico de la mujer, según lo razonado en el considerando anterior". Lo reitera en el considerando siguiente señalando: "que el daño que se indemniza no es el que ocasiona el divorcio en sí mismo, sino el menoscabo que proviene directamente del o los actos culpables generadores de responsabilidad extracontractual que los tribunales del grado tuvieron por legalmente establecidos en el proceso".

Por lo visto, existe prácticamente unanimidad en la doctrina y jurisprudencia en cuanto que la infracción estatutaria de los deberes del matrimonio que constituye un ilícito penal genera indemnización de perjuicios. Así, el profesor David Vargas señala que un buen número de autores, que niegan la indemnización de perjuicios por daño moral, por incumplimiento de deberes del matrimonio, la admite en materia de responsabilidad penal y cita a Roca I Trias, Ferrer Riba y Rodríguez Gutián. ${ }^{29}$ Ya se indicó que el profesor Severín adhiere a la posición de "obtener una reparación de los casos en que ha existido algún tipo de violencia intrafamiliar, a la vez que la cerramos, por

${ }^{29}$ Vargas Aravena, David, "Del Resarcimiento en Chile de los daños causados en el matrimonio", Revista Ius et Praxis (Universidad de Talca), 2015, Año 21, N 1, pp. 57-100. 
ejemplo, para el adulterio, el alcoholismo, la conducta homosexual, etc.". ${ }^{30}$

Sin embargo, ha de insistirse que estos casos no son más que la aplicación de las reglas generales de la responsabilidad civil, siendo indudable que procede la indemnización del daño cuyo origen constituye un ilícito, tanto penal como civil, incluyendo los delitos y cuasidelitos, como el manejo descuidado de un cónyuge que produce la lesión o la muerte del otro, la violación de los hijos, maltrato físico o psicológico al otro cónyuge o a los hijos, la suplantación de identidad, acompañada de secuestro de menores, etc. Pueden sumarse algunos casos dudosos, que se presentan sobre todo en los cuasidelitos penales y civiles, como el envenenamiento culposo de un cónyuge a otro, que es alérgico y que produce su muerte o graves consecuencias, las injurias entre cónyuges o la develación vía redes sociales de aspectos o situaciones que pueden considerarse personales o íntimas. Estas conductas, si bien transgredirían los deberes recíprocos de cuidado y respeto, que se deben los cónyuges, es discutible que necesariamente deban generar una indemnización de perjuicios y es así como es dable concluir que la responsabilidad civil no puede ser una consecuencia automática de la infracción de todo deber conyugal. De lo que no cabe duda es que de haber responsabilidad penal estamos en presencia de supuestos que potencialmente pueden dar lugar a la responsabilidad civil entre cónyuges. ${ }^{31}$

\subsection{El deber de fidelidad}

Es precisamente en este deber donde se centra la atención de la doctrina sobre la procedencia de la responsabilidad civil en los casos de adulterio y es cierto, desde la lectura de una variedad de autores, que en sus argumentos no dejan de incluirse posiciones valóricas o culturales que es necesario atender y de hecho, ésta ha sido la materia que con mayor frecuencia ha llegado a los tribunales, tanto por el incumplimiento mismo como por las situaciones consecuenciales creadas en el interior de la familia.

El deber de fidelidad implica obviamente la obligación de abstenerse de tener relaciones sexuales con terceras personas cuando se está bajo el vínculo matrimonial; de partida, es un deber que sólo puede ser descrito en su fase negativa "no incurrir en relaciones impropias al estado de casado", por cuanto en su descripción positiva no da derecho a exigir su cumplimiento mediante relaciones sexuales a la fuerza, so pena de incurrir en el delito de violación.

\footnotetext{
${ }^{30}$ SeVerín Fuster, cit. (n. 27).

${ }^{31}$ Barcia Lehmann y Rivera Restrepo, cit. (n. 23).
} 
La jurisprudencia nacional ha sido constante en calificar la fidelidad como un deber ético-moral, de manera tal que la infidelidad, aun cuando cause daño, no da lugar a indemnización alguna. ${ }^{32}$ Destaca en la sentencia de la Corte de Santiago (Rol 7738-2007), la cita al autor italiano Roberto de Ruggiero, quien expresa que: "antes que jurídico, la familia es un organismo ético. De la ética, en efecto, proceden los preceptos más esenciales que la ley presupone y a los cuales hace constante referencia, apropiándoselos a veces y transformándolos de este modo en preceptos jurídicos; por ello se explica el fenómeno peculiar en el derecho de familia, de haber preceptos sin sanción o con sanción atenuada, obligaciones incoercibles, porque el derecho, o es por sí mismo incapaz de provocar mediante la coerción la observancia de dichos preceptos, o cree más conveniente confiar su observancia al sentido ético, a la costumbre, a otras fuerzas que actúan en el ambiente social". Concluyen, en consecuencia que: "el hecho que el adulterio siempre haya tenido una sanción especial, establecida por el legislador en consideración a la naturaleza de la institución del matrimonio, piedra fundamental del derecho de familia, no permite considerarlo fuente de responsabilidad extracontractual como lo pretende el demandante, pues las normas que regulan tales materias se refieren a la reparación de daños derivados de obligaciones de carácter patrimonial, motivo por el cual no resulta jurídicamente procedente acoger la presente demanda" (considerando vigesimoprimero).

Básicamente, los tribunales esgrimen como argumentos los siguientes: a) los deberes matrimoniales son extrapatrimoniales y tienen un contenido ético que trasciende lo jurídico; b) el legislador, a la época en que ocurrieron los hechos y también hoy, establece sanciones específicas para la infracción de los deberes conyugales y específicamente por la grave conducta del adulterio; y c) resulta inviable aplicar el estatuto de la responsabilidad extracontractual ya que no puede calificarse el adulterio como delito o cuasidelito civil ya que no es posible decir que se es infiel con dolo o por culpa. ${ }^{33}$

\footnotetext{
${ }^{32}$ Sentencia de la Corte de Apelaciones de Rancagua, 29 de octubre de 2007, Rol No 672-2007; Corte de Apelaciones de Santiago, 10 de noviembre de 2009, Rol No 7738-2007; Corte de Apelaciones de Puerto Montt, 20 de diciembre de 2010, Rol No 181-2010; Corte de Apelaciones de Puerto Montt, 20 de diciembre de 2010, Rol N 181-2010.

${ }^{33}$ La sentencia de la Corte de Apelaciones de Puerto Montt, dictada en la causa Rol N ${ }^{\circ} 181-2010$, considera además que "pretender una indemnización por daño moral por una presunta relación extramatrimonial de uno de los cónyuges, es contraria al orden público, ya que aún en el caso de ser comprobada estaríamos frente a lo que el artículo 132 del Código Civil considera una grave infracción al deber de fidelidad que impone el matrimonio, lo que según el mismo artículo da origen a las sanciones que la ley prevé, entre las cuales por cierto, las normas de orden público que regulan el matrimonio, no ha considerado la indemnización por daños morales al otro cónyuge".
} 
Entre los críticos de esta postura se encuentra el profesor Corral Talciani, quien indica que: "La supuesta inmunidad familiar puede servir para exigir un parámetro más alto de cuidado pero no para tolerar toda conducta ilícita". Afirma que: "la raigambre ética o no patrimonial de los derechos familiares no puede ser un obstáculo para pedir reparación del daño"; "El que haya otras sanciones previstas para el adulterio no significa que no se pueda pedir reparación de los daños causados. La responsabilidad civil no opera como sanción, no tiene fines punitivos, sino como un instrumento de justicia correctiva o restauradora (...) es claro que quien comete adulterio lo hace con dolo, pues hay una intención positiva de inferir injuria (injusticia) a la persona de otro (art. 44 Código Civil)". ${ }^{34}$

Le sigue la profesora María Sara Rodríguez quien, comentando la sentencia referida, sostiene que el adulterio constituye una infracción al deber de fidelidad y por ello, un hecho ilícito que ha de imputarse a los demandados (el marido y la mujer con quien tuvo un hijo fuera del matrimonio), existiendo un daño patrimonial y moral que este hecho ilícito le ha causado a la demandante que debe ser indemnizado. Postula el error en la argumentación de los tribunales por cuanto: "Los deberes de familia, incluidos los deberes emanados del matrimonio, son obligaciones jurídicas, muchas de ellas exigibles coactivamente y todas con sanciones legales por su infracción. No pueden calificarse, como hace el fallo recurrido, como deberes ético-morales que sólo obligarían en conciencia. La infracción de estas obligaciones, por el contrario, configura un hecho ilícito que, si causa daño, es un delito civil, por el que también debería poder exigirse la indemnización de perjuicios". ${ }^{35}$

Se suma también a esta crítica el profesor Mario Opazo González, quien menciona que "el adulterio es un delito civil, por cuanto hay un hecho antijurídico que causa daño y evidentemente hay dolo, lo que ocurre es que la Corte olvidó que la doctrina contemporánea ha sostenido que el dolo extracontractual no se restringe al dolo directo sino también al dolo eventual (...) En caso de adulterio habrá dolo eventual pues el cónyuge adúltero puede anticipar el daño y no obstante ello lo acepta"; ${ }^{36}$ y la profesora Jimena Valenzuela del Valle quien sostiene, entre otros motivos, que "Las obligaciones

\footnotetext{
${ }^{34}$ Corral Talciani, cit. (n. 1).

${ }^{35}$ RodríguEz, María Sara, "Indemnización de perjuicios por infracción al deber de fidelidad en el matrimonio", Columna publicada en El Mercurio Legal el miércoles 25 de julio de 2012, recurso electrónico disponible en línea: https://msararodriguez.wordpress.com/tag/deber-de-fidelidad/ .

${ }^{36}$ Opazo GonzÁlez, Mario, "El Principio de la reparación Integral del Daño y los Daños causados por Adulterio", en Elorriaga de B., F. (Coord.), Estudios de Derecho civil VII, Jornadas Nacionales de Derecho Civil, Viña del Mar 2011, Abeledo Perrot-Thomson Reuters, Santiago, 2012, pp. 589-606.
} 
matrimoniales serían obligaciones morales si solo tuvieran sanciones también morales; y no es así. Tienen sanciones civiles especiales y no están exentas de la sanción civil residual por antonomasia que es la obligación de indemnizar los daños y perjuicios causados por su infracción". ${ }^{37}$

Esta opinión tuvo reconocimiento en la sentencia dictada por la Corte de Apelaciones de Talca, con fecha 30 de agosto de 2012, ${ }^{38}$ la que parte descartando el argumento de especialidad de las normas del Derecho de Familia señalados anteriormente por la Corte de Santiago; a continuación este tribunal se manifiesta partidario de la posibilidad de indemnizar los daños y perjuicios que se produzcan por incumplimiento de los deberes matrimoniales. Cabe consignar que en este caso fue la cónyuge quien presentó demanda de indemnización de perjuicios por daños materiales y morales en contra de su marido, fundada en la responsabilidad civil extracontractual como consecuencia de haberla contagiado del virus del papiloma humano (HPV), producto de sus repetidas infidelidades matrimoniales, lo cual la llevó finalmente a someterse a una histerectomía total. En este fallo se indica: "que pese a que los deberes conyugales son incoercibles directamente, son "auténticos deberes jurídicos exigibles legalmente" (considerando décimo). También sostuvo que "seguimos a la doctrina comparada que sobre el particular se inclina mayoritariamente por la posibilidad de indemnizar los daños y perjuicios que se produzcan por el incumplimiento de los deberes matrimoniales. No se vislumbra ninguna buena razón para impedir, a priori, una posible indemnización por el incumplimiento de los deberes matrimoniales" (considerando octavo).

La postura de los autores precedentes ha sido catalogada como representativa de una ideología conservadora e influenciada en convicciones religiosas -principalmente cristianas- que en su momento también se expresaron como oposición a la ley del divorcio y que, en definitiva, prosperaron al obtener la incorporación de reglas que lo hicieran más gravoso, como las limitaciones de la acción que imponen los artículos 54 y 55, por lo que siguiendo ese mismo interés, ahora pretenderían introducir la posibilidad de ser sujeto de una acción de indemnización de perjuicios, con lo que insisten en entorpecer o desincentivar el ejercicio de la acción de divorcio.

Al contrario de las referidas posturas, la otra tendencia doctrinal, que aplaude a la jurisprudencia mayoritaria de nuestros tribunales, señala que el

\footnotetext{
${ }^{37}$ Valenzuela del Valle, cit. (n. 17); también en recurso electrónico, disponible en línea: http:// derechodefamiliachileno.blogspot.cl/2015/06/responsabilidad-civil-por.html.

${ }^{38}$ Corte de Apelaciones de Talca, 30 de agosto de 2012, Rol Corte No 133-2012. Sin embargo, la sentencia rechaza la demanda al no haberse acreditado la relación causal entre la infracción y el daño.
} 
respeto a la fidelidad dentro del matrimonio obedecería a una decisión que emana del fuero interno de las personas y que los jueces no pueden entrar a calificar como bueno o malo e incidir en su conducta a través de la indemnización de perjuicios. " $Y$ ello es evidente porque si se admite el daño moral por incumplimiento del deber de fidelidad en el matrimonio, ¿por qué no admitirlo en las relaciones de otra indole en que haya un compromiso entre las parejas no casadas? o en general ifrente a cualquier incumplimiento de un deber jurídico/ético? Como se aprecia de estas preguntas estamos ingresando en un área respecto de la cual el Derecho moderno, o posmoderno, ha tenido el cuidado de no invadir, como es la privacidad y dignidad del ser humano". ${ }^{39}$

"Fuera de los casos en los que la conducta del cónyuge sea constitutiva de delito o lesione un derecho fundamental del otro, el incumplimiento de los deberes conyugales no es indemnizable". ${ }^{40}$ Una infracción de los deberes conyugales, aun cuando sea grave y reiterada, no podrá ser indemnizada sino en cuanto se trate de un ilícito y que admita la procedencia de los otros presupuestos de la responsabilidad extracontractual, como lo es la antijuridicidad e imputabilidad de la lesión resarcible. La misma Esther Algarra, haciendo alusión a la doctrina italiana -Luigi Gaudino- menciona que el matrimonio, en definitiva, no puede reducir la protección a los derechos fundamentales de un cónyuge por la actuación de otro, pero tampoco puede ampliar la protección del interés en el cumplimiento de sus reglas, cuando la actuación no sea constitutiva de delito ni lesiones de los derechos fundamentales. Agrega también -refiriéndose a Miquel Martin-Casals y Jordi Ribot- que incluso en aquellos ordenamientos jurídicos que parten de una cláusula general de responsabilidad deben analizarse y sopesarse los intereses en juego para no convertir las reclamaciones indemnizatorias en una intolerable cortapisa a las libertades individuales.

La Dra. Española Aurelia Maria Romero Coloma refiere que los tribunales alemanes consideran que las infracciones a deberes conyugales son incompatibles con la naturaleza del matrimonio y, por ello, son reacios a conceder indemnizaciones por infracciones al interior de la familia, afirmando que ellas se rigen por su propio derecho, Excepcionalmente ha permitido la indemnización por adulterio cuando hay intensión cualificada de causar daño y ello concurre cuando el cónyuge hace afirmaciones o genera una escena que permite el engaño, pero no cuando omite los hechos, porque ninguno de ellos tiene obligación de confesar el adulterio. En España, la autora refiere una

\footnotetext{
39 Barcia Lehmann y Rivera Restrepo, cit. (n. 23).

${ }^{40}$ Algarra Prats, cit. (n. 13).
} 
tendencia de los tribunales para negar las indemnizaciones por infidelidad y en argumentar un régimen de inmunidad al interior de la familia más provechoso, dadas las relaciones que se generan, pero sostiene que ello más bien se explica en el temor que existe de verse sobrepasados por una avalancha de demandas de este tipo. ${ }^{41}$

\section{EL EJERCICIO DE LA ACCIÓN DE DIVORCIO COMO CAUSAL DE RESPONSABILIDAD CIVIL}

No se había planteado la reparación de los daños por el ejercicio de la acción de divorcio, por cuanto aquella es una facultad de los cónyuges que se deduce cuando se cumplen los requisitos de hecho que señalan la ley, hasta que la profesora Jimena Valenzuela del Valle ${ }^{42}$ la defendió en los casos que denominó "ejercicio abusivo de la acción de divorcio unilateral".

Es abusivo el ejercicio del derecho cuando está impregnado de una inequívoca intensión de dañar (abuso del derecho en sentido subjetivo) como también si según las circunstancias del caso contradice estándares mínimos de sociabilidad y lealtad (abuso del derecho en sentido objetivo). A juicio de la autora el abuso del derecho es un hecho ilícito que admite la posibilidad de indemnizar perjuicios.

Explica la autora que cuando el derecho se utiliza solo para causar daño, queda en evidencia al existir una extrema desproporción entre el interés del titular en relación al efecto negativo que produce en otra persona el ejercicio del derecho. Esta situación la extrapola al divorcio cuando el cónyuge que lo pretende lo hace de mala fe con la intención de causar daño, por lo que debe indemnización por los perjuicios que cause. Lo ejemplifica en las circunstancias de ancianidad, enfermedad, precariedad económica, dependencia del cónyuge demandado, niños menores especialmente necesitados, donde el efecto negativo del divorcio puede ser más funesto que el beneficio que se persigue y por tanto, desproporcionado e innecesario.

Como se indicó al inicio de este capítulo, se trata de una opinión aislada que no apoya ningún profesor de la materia, ${ }^{43}$ asimismo, no fue incluida en

\footnotetext{
${ }^{41}$ Romero Coloma, Aurelia, Incumplimiento de deberes conyugales y derecho a la indemnización, Editorial Reus, Madrid, 2012, p. 27; p. 38.

42 Valenzuela del Valle, cit. (n. 17).

${ }^{43}$ Vargas Aravena, David, "Del Divorcio y la responsabilidad civil", Revista de Derecho de Familia, 2014, № 3, pp. 139 ss.; Turner SaElzer, Susan, "Deberes personales derivados del matrimonio y daños en la jurisprudencia chilena”, en Domínguez, C.; González, J.; Barrientos, M; Goldenberg, J. (Coords.), Estudios de Derecho Civil VIII, Thomson Reuters, Santiago, 2012, pp. 165-173; SEverín Fuster, cit.
} 
el proyecto de ley de divorcio y se basa en concepciones sobre la idea del matrimonio para toda la vida que expresa el artículo 102 del Código Civil, unida a las obligaciones que se le imponen al juez para instar a los cónyuges a preservar el vínculo matrimonial.

Pero lo cierto es que el ejercicio de una facultad legal no puede calificarse como contraria a derecho, por lo que el daño que puede ocasionar el divorcio en sí mismo, no puede ni debe ser indemnizado, ya que no existe antijuridicidad del hecho, puesto que el divorcio es una institución legal para otorgar marco jurídico a la situación de hecho que provoca la ruptura de otra institución jurídica como lo es el matrimonio. En este sentido, no puede desconocerse que, en la mayoría de los casos, el ejercicio de la acción de divorcio o su declaración producen daños de naturaleza emocional al verse frustrada la esperanza del cónyuge de lograr una familia legítimamente constituida, las proyecciones de vida tanto en sus aspectos materiales o personales o simplemente, por el sólo hecho de verse expuesto a la disolución de un matrimonio que conforme a sus creencias personales es indisoluble; pero en ninguno de estos casos podrán ser resarcidos estos daños por el cónyuge solicitante de la declaración, puesto que la facultad de divorciarse se convierte en una causa de justificación de los mismos y de exclusión de responsabilidad, transformándolos en "lícitos y justos" y que, de no existir, conduciría a la correspondiente obligación resarcitoria. ${ }^{44}$

La teoría del abuso del derecho que pretende plantear la profesora Valenzuela no puede tener cabida en nuestro derecho, por cuanto el que ejercita una acción legal no causa daño y no corresponde entrar a valorar o enjuiciar la moralidad o inmoralidad de su ejercicio o de la frustración que provoca la pérdida de la esperanza del matrimonio para toda la vida o los ideales y promesas comprometidos al momento de contraerlo.

Por otra parte, no es el ejercicio de la acción de divorcio un presupuesto legal necesario o requisito de admisibilidad para perseguir la responsabilidad civil por los daños causados por infracción de deberes conyugales, en los casos que procediere de acuerdo a las posiciones expuestas en este trabajo, puesto que ellas pueden obrar con independencia, más aún si se considera que la prescripción ha empezado a correr desde el acontecimiento de la infracción y no desde que así se declare como causal en el respectivo divorcio. ${ }^{45}$

(n. 27); Corral Talciani, Hernán, “Adaptación de la responsabilidad civil en los procesos de familia. La experiencia chilena de la Compensación Económica en caso de nulidad matrimonial y divorcio", Ars Boni et Acque (U. Bernardo O'Higgins), 2008, № 4, pp. 81-89; en línea: http://arsboni.ubo.cl/index.php/ arsbonietaequi/article/view/186/169.

${ }^{44}$ También es la opinión expresada por el profesor VARgas Aravena, cit. (n. 43).

${ }^{45}$ V. Corte Suprema, 24 de noviembre de 2016, Rol No 45.802-2015. Acoge casación y declara prescrita 


\section{ALGUNAS POSTURAS DE LA JURISPRUDENCIA EXTRANJERA}

En Italia, una sentencia del Tribunal de Milán de 10 de febrero de 1999 reconoció el resarcimiento de daños por infracción del recíproco deberderecho a las relaciones sexuales entre los cónyuges, lo que configura como un derecho inviolable constitucionalmente, pero finalmente rechazó la demanda solo por falta de establecimiento de la relación causal. ${ }^{46}$ Se trataba de un matrimonio celebrado en el año 1965, donde el marido siempre demostró un marcado desinterés sexual que en 1966 fue diagnosticado como "carencia de masculinidad", inicia terapia pero finalmente la abandona en 1970, se divorcian en 1977 y la mujer lo demanda por que la indiferencia e incapacidad sexual del cónyuge le había ocasionado un trastorno ansioso depresivo y frustración de sus expectativas.

En sentencia de la Corte de Apelaciones de Turín, de 21 de febrero de 2000, se acoge la demanda de la mujer en contra de su cónyuge, del cual están separados, elaborando un concepto de Mobbing para describir que al interior del matrimonio ella era ofendida permanentemente delante de la familia y amigos, exteriorizando sólo valoraciones negativas e invitándola permanentemente a hacer abandono de la casa. A juicio del tribunal el cónyuge violó el principio de igualdad moral y jurídica de los cónyuges y en particular el deber de lealtad y fidelidad, haciendo referencia a la vulneración de los derechos fundamentales de la persona y al umbral mínimo de solidaridad, respeto necesario y debido a la personalidad del cónyuge. ${ }^{47}$

Por sentencia de 13 de junio de 2000 de Tribunal de Florencia, se condenó civilmente por infracción a los deberes de cuidado y socorro al marido que no asistió a su mujer que padecía una esquizofrenia paranoide. Ello se debió, conjuntamente con otras circunstancias -la mujer pasó encerrada durante cuatro años en un cuarto en condiciones de degradación física y psíquica-, al hecho de no recibir a su cónyuge en su hogar una vez que estaba recuperada, desechando las instrucciones médicas que aconsejaban hacerlo.

En España destacan dos sentencias del Tribunal Supremo de 22 de julio de 1999 y 30 de julio de 1999, con situaciones fácticas bastantes semejantes. En ambos casos los matrimonios tenían hijos respecto de quienes se había otorgado pensión de alimentos y, luego de la separación, se producen impugnaciones de

la acción de indemnización por existencia de malos tratos en el matrimonio declarados en el juicio de Divorcio seguido ante el Segundo Juzgado Civil de Chillán, Rol C-1670-2013.

${ }^{46}$ Mencionada en Marín García de Leonardo, cit. (n. 13).

${ }^{47}$ Marín García de Leonardo, cit. (n. 13). 
paternidad que son acogidas. Los maridos reclaman civilmente indemnización de perjuicios por el comportamiento doloso de la madre al haberle ocultado durante años la verdadera paternidad de sus hijos y piden resarcir el valor de los alimentos otorgados. En ambas sentencias se rechazan las respectivas demandas, en el primer caso, por no estar acreditado el dolo de la madre y, en el segundo caso, si bien se establece el dolo de la cónyuge, se afirma que el adulterio de la mujer no es indemnizable y respecto de los alimentos, indicaron que debía impetrar su devolución al verdadero padre. ${ }^{48}$

Por sentencia de la Audiencia Provincial de Valencia de 2 de noviembre de 2004, se condena solidariamente a la mujer y a su amante al pago de los daños patrimoniales y morales causados al esposo, sin embargo, la indemnización concedida no fue por el incumplimiento al deber de fidelidad, sino por las consecuencias que se generaron por cuanto los tres hijos menores no eran del cónyuge, es así que se indemnizó el detrimento de la fama, honor y prestigio profesional. Estiman los jueces que hubo una conducta dolosa de los demandados que ocultaron, a sabiendas, que los hijos no eran del esposo y aunque la infidelidad en sí no es susceptible de reparación económica, sí lo es la frustración, quebranto o ruptura de los sentimientos, lazos o afectos que por naturaleza se dan entre personas allegadas, en definitiva, estima que la pérdida de los que consideraba sus hijos tiene una entidad semejante a la pérdida física de éstos y se ha producido un daño moral innegable. ${ }^{49}$

La Audiencia Provincial de Barcelona, en sentencia de 16 de enero de 2007, entiende que basta la culpa y negligencia en el obrar y excluye necesariamente el dolo, pues aun cuando la mujer tuvo la duda de que su marido era el padre de su hijo, tenía la certeza de haber tenido relaciones sexuales extramatrimoniales, por lo que pudo y debió sospechar que podía ser otro el padre. La sentencia la condena a indemnizar al cónyuge pero no por la infidelidad en sí, sino por el daño sufrido por el marido al privársele del hijo o hijos entendidos como propios. En los mismos términos lo expresó la Sentencia de la Audiencia Provincial de Cádiz de 3 de abril de 2008. ${ }^{50}$ Ambas son una excepción a la tendencia jurisprudencial española que ha exigido el dolo explícito.

En Francia, ya en sentencia de la Corte de Casación de 9 de noviembre de 1965, se había concedido una indemnización a la esposa por los perjuicios sufridos como consecuencia de la negativa de su marido a admitirla en el

\footnotetext{
48 Ídem.

49 Ídem.

${ }^{50}$ Algarra Prats, cit. (n. 13).
} 
domicilio conyugal, aplicándose los principios generales del derecho de daños. ${ }^{51}$ La misma Corte de Casación, mediante fallo de 6 de julio de 2005, en un caso donde existía sentencia de divorcio por culpa de uno de los cónyuges, deja entrever que la declaración de divorcio constituía en sí misma la reparación de un perjuicio y fija la doctrina por la cual se debe rechazar una demanda de indemnización de daños cuando no se constata un perjuicio distinto al causado por la disolución del matrimonio.

El máximo tribunal Alemán admite que en estas cuestiones sólo caben las sanciones previstas en el Derecho de Familia, descartando cualquier acción civil entre los cónyuges destinados a reparar daños y perjuicios causados por incumplimiento de deberes matrimoniales. Las demandas deducidas por cónyuges en casos de infidelidad son rechazadas sin distinción, también han sido rechazadas demandas pidiendo el resarcimiento de los dineros entregados por la manutención de un hijo que no era del cónyuge. Sólo ha admitido excepcionalmente la indemnización cuando ha habido intensión cualificada de causar daño. ${ }^{52}$

En Argentina, hace más de 25 años se dictó el primer fallo que hizo lugar a una demanda por daños y perjuicios en materia de derecho de familia, producido por la falta de reconocimiento de un hijo, y desde allí la jurisprudencia ha aceptado la responsabilidad por daños ocasionadas en el ámbito familiar en todos los ámbitos, sobre todo en el divorcio, la falta de reconocimiento de hijos, la violencia doméstica y el impedimento de contacto con los hijos menores por parte del progenitor que tiene la custodia. ${ }^{53}$ Sin embargo, en 1998 se establece un sistema de divorcio incausado y se suprime el deber de fidelidad como deber jurídico, limitándolo a un deber moral, provocando sentencias que rechazan el daño por dicho motivo, salvo excepciones.

\section{CONCLUSIÓN}

La problemática del tema que nos ocupa no radica en admitir o negar que puedan existir daños en las relaciones conyugales, sino que en aceptar o rechazar que el mero incumplimiento de los deberes conyugales recogidos en el Código Civil pueda dar lugar a estos daños y que ellos sean susceptibles de amparo y reparación por la vía dispuesta en los artículos 2314 y siguientes del Código Civil. Tampoco se trata de rechazar la incursión del derecho de daños

\footnotetext{
${ }^{51}$ Barcia Lehmann y Rivera Restrepo, cit. (n. 23).

${ }^{52}$ Romero Coloma, cit. (n. 41).

${ }^{53}$ Medina, cit. (n. 2).
} 
en las relaciones conyugales sino que acotar el camino al cual debe adscribir nuestra postura, para evitar que cualquier incumplimiento de un deber conyugal sea suficiente para reclamar un daño.

Es preciso, sin embargo, reconocer que la fidelidad constituye un deber jurídico y no sólo una exigencia moral; pero la razón por la cual no puede ser indemnizada su contravención viene dada por que su incumplimiento no genera los efectos de las obligaciones, precisamente por carecer de una acción que la pueda hacer exigible. Para el caso de los daños que pueda provocar una infidelidad es necesario reconocer que no existe una relación causal tan clara entre la infracción y el daño, ya que dicho daño podría obedecer a otras fuentes, como lo sería, alguna particular condición de quien se considera víctima, su autoestima, la repercusión del "engaño", la interrupción de su concepción de familia, todo lo cual si bien puede conllevar una repercusión en su estado anímico, en términos objetivos no obedece sólo a la conducta del infractor, por lo que no le serían imputables. Asimismo, el dolo o la culpa en el obrar del agente aparecen extraños o de difícil descripción, cuando se trata de un obrar estimulado por la cultura, las concepciones religiosas o ideológicas o derechamente, las pasiones.

Distinto es el caso, por cierto, en que el daño se evidencia a través de afectaciones de bienes jurídicos como la salud y la integridad física del cónyuge, pero ya se advirtió que aquellos no se definen en base a una infracción pura a deberes conyugales, sino que a obligaciones genéricas de no dañar a nadie, puesto que aun suprimiendo la relación matrimonial existente, el daño se configura igualmente y los resultados lesivos de la conducta siguen produciendo los mismos efectos que pueden ser resueltos bajo las normas de la responsabilidad extracontractual del derecho común.

El derecho debe ser neutral y sus soluciones deben limitarse a recomponer la relación o formalizar la ruptura de la forma menos traumática posible, sin intentar trazar un modelo determinado de relación; a partir de ello, no es posible pretender sancionar la moralidad que conlleva la infidelidad o el adulterio o construirla como un ilícito dentro de la responsabilidad civil, otorgando a los jueces facultades para entrar en tales ámbitos de intimidad de los cónyuges y definir lo bueno o malo de tales acciones. Un matrimonio puede autónomamente decidir que mantendrá su relación a pesar de no cohabitar transitoria o permanentemente, así como también una pareja considerar que la exclusividad sexual no es un elemento determinante de su vínculo, todas estas decisiones pertenecen a la familia y el derecho no puede inmiscuirse por respeto a la libertad de las personas.

En sentido inverso, el derecho debe intervenir cuando el incumplimiento de los deberes conyugales provoca la violación de los derechos del otro cónyuge, 
pero ello no es una excepción a lo resuelto en cuanto la imposibilidad de indemnizar la infracción de los deberes conyugales, sino que es una aplicación de los principios generales del derecho de daños, aplicables con independencia del vínculo conyugal.

\section{BIBLIOGRAFÍA}

Algarra Prats, Esther, "Incumplimiento de deberes conyugales y Responsabilidad Civil", en Moreno Martínez, Juan A. (Coord.), La responsabilidad Civil en las Relaciones Familiares, Dykinson, Madrid, 2012.

Barcia Lehmann, Rodrigo; Rivera Restrepo, José M., "¿En qué casos el incumplimiento de deberes del matrimonio genera responsabilidad civil?", Revista Ius et Praxis (Universidad de Talca), 2015, Año 21, № 2, pp. 19-60.

CÉSPedes MuÑoz, Carlos; VARgas, David, "Acerca de la naturaleza jurídica de la compensación económica. La situación en Chile y en España", Revista Chilena de Derecho, 2008, Vol. 35, No 3, pp. 439 - 462.

Cornejo García, María Gloria, "Particularidades de la responsabilidad civil extracontractual en el Derecho de Familia", Universidad de Chile, Memoria de Prueba de Pregrado, Santiago, 2012; recurso electrónico disponible en línea: http://repositorio.uchile.cl/bitstream/handle/2250/112811/de-cornejo_m. pdf?sequence $=1$.

Corral Talciani, Hernán, "La compensación económica en el divorcio y la nulidad matrimonial", Revista Chilena de Derecho, 2007, vol. $34 \mathrm{~N}^{\mathrm{o}} 1$, pp. 23 - 40, disponible en línea: http://www.scielo.cl/scielo.php?script=sci_arttext\& pid $=$ S0718-34372007000100003.

Corral Talciani, Hernán, "Adaptación de la responsabilidad civil en los procesos de familia. La experiencia chilena de la Compensación Económica en caso de nulidad matrimonial y divorcio", Ars Boni et Acque (U. Bernardo O'Higgins), 2008, № 4, pp. 81-89; en línea: http://arsboni.ubo.cl/index.php/ arsbonietaequi/article/view/186/169.

Corral Talciani, Hernán, "La Incipiente Jurisprudencia Chilena sobre Daños en Familia", Revista de Derecho de Familia, 2014, № 4, pp. 51-60.

Domínguez Águila, Ramón: "La compensación económica en la nueva legislación de matrimonio civil”, Actualidad Jurídica (UDD), 2007, No 15, pp. 83-92.

Domínguez Hidalgo, Carmen, "El convenio regulador y la compensación económica: una visión en conjunto", en Universidad de los Andes (Editor), Cuadernos de extensión jurídica, 2005, N 11, pp. 120-121. 
Etcheberry Orthusteguy, Alfredo, Derecho Penal, Parte General, Editorial Jurídica de Chile, Santiago, 1999, Vol. II, Reimpresión de la $3^{\text {a }}$ edición, $492 \mathrm{pp}$.

GonzÁlez Cazorla, Fabián, "Incumplimiento de deberes conyugales y acciones indemnizatorias: Un análisis sobre su procedencia", Derecho y Justicia (U. Católica Silva Henríquez), 2014, N 4, recuso electrónico disponible en línea: http://ediciones.ucsh.cl/ojs/index.php?journal=derechoyjusticia\&page=article \&op=view\&path $\% 5 \mathrm{~B} \% 5 \mathrm{D}=731$; consultada en la siguiente dirección: https:// www.academia.edu/19067168/Incumplimiento_de_deberes_conyugales_y_ acciones_indemnizatorias._Un_an\%C3\%A1lisis_sobre_su_procedencia.

HERANE Vives, Francisco, "Reparación por incumplimiento de los deberes matrimoniales", en Corral T., H; Rodríguez P., M. S. (Editores), Estudios de Derecho Civil II, LexisNexis, Santiago, 2007, pp. 181-193; también en AA.VV., Estudios de Derecho Civil, Familia y Derecho Sucesorio, Abeledo PerrotThomson Reuters, Santiago, 2015, T. V., pp. 105 y ss.

Marín García de Leonardo, Teresa, "Remedios Indemnizatorios en el Ámbito de las Relaciones Conyugales", Revista Aranzadi de Derecho Patrimonial (España), 2006, № 17.

Medina, Graciela, "Daños en el Derecho de Familia en el Código Civil y Comercial Unificado", Revista de Derecho de Familia y Sucesiones (Argentina), 2015, No 5 (Sept.), 07-09-2015, Cita IJ-LXXX-322; recurso disponible en línea: http://www.gracielamedina.com/assets/Uploads/medina.pdf.

Medina, Graciela; Roveda, Eduardo G., Derecho de Familia, Abeledo Perrot, Buenos Aires, 2016, 1024 pp.

Novales Alquezar, Aranzazu, "Responsabilidades Especiales, ¿Debieran haber en el Derecho Matrimonial Mecanismos reparatorios?", en AA.VV., Regímenes especiales de responsabilidad civil, Cuadernos de Análisis Jurídicos, Colección Derecho Privado IV, Ediciones Universidad Diego Portales, Santiago, 2008, pp. 119-150.

Opazo GonzÁlez, Mario, "El Principio de la reparación Integral del Daño y los Daños causados por Adulterio", en Elorriaga de B., F. (Coord.), Estudios de Derecho Civil VII, Jornadas Nacionales de Derecho Civil, Viña del Mar 2011, Abeledo Perrot-Thomson Reuters, Santiago, 2012, pp. 589-606.

Ramos Pazos, René, Derecho de Familia, Editorial Jurídica de Chile, Santiago, 2010, $7^{\text {a }}$ edición, T. I.

RoDríguez, María Sara, "Indemnización de perjuicios por infracción al deber de fidelidad en el matrimonio", Columna publicada en El Mercurio Legal el miércoles 25 de julio de 2012, recurso electrónico disponible en línea: https:// msararodriguez.wordpress.com/tag/deber-de-fidelidad/.

Romero Coloma, Aurelia, Incumplimiento de deberes conyugales y 
derecho a la indemnización, Editorial Reus, Madrid, 2012; disponible también en línea: https://books.google.cl/books?id=TwSoBQAAQBAJ\&pg=PA81\&dq= responsabilidad + deberes + conyugales + coloma\& $h l=e s \& s a=X \& v e d=0 a h U K E w$ jnpNLnrfnQAhVCjJAKHX8_CO0Q6AEILTAA\#v $=$ onepage $\& \mathrm{q}=$ responsabilid ad $\% 20$ deberes $\% 20$ conyugales $\% 20$ coloma\&f $=$ false

SEVERín Fuster, Gonzalo, "Indemnización entre cónyuges por los daños causados con ocasión del divorcio", en AA.VV., Estudios de Derecho Civil, Familia y Derecho Sucesorio, Abeledo Perrot-Thomson Reuters, Santiago, 2015, T. V, pp. 165 y ss.

TAPIa Rodríguez, Mauricio, "Aproximación Crítica a la Indemnización de Perjuicios por Incumplimiento de Deberes Conyugales", en Vidal Olivares, Á; Severin Fuster, G; Mejías Alonzo, C. (Coords.) Estudios de Derecho Civil X, Thompson Reuters, Santiago, 2015, pp. 231-248.

TAPIA Rodríguez, Mauricio, "El incumplimiento de deberes conyugales no da lugar a la indemnización de perjuicios", Revista de Estudios Judiciales, 2016, Nos 2-3 (Thomson Reuters, Santiago), pp. 137-144.

Turner Saelzer, Susan, "Sentencia sobre requisitos de procedencia y finalidad de la compensación económica (Corte de Apelaciones de Valdivia)", Revista de Derecho (Valdivia), 2006, Vol. 19, N² 2, pp. 272-273.

Turner Saelzer, Susan, "Deberes personales derivados del matrimonio y daños en la jurisprudencia chilena”, en Domínguez, C.; González, J.; Barrientos, M; Goldenberg, J. (Coords.), Estudios de Derecho Civil VIII, Thomson Reuters, Santiago, 2012, pp. 165-173.

Valenzuela del Valle, Jimena, "Responsabilidad Civil por el incumplimiento de obligaciones matrimoniales y por el ejercicio abusivo del divorcio unilateral. Un estudio de su admisibilidad en Chile", Revista de Derecho Universidad Católica del Norte, 2012, № 1, Año 19, pp. 241-269.

Vargas Aravena, David, "Del Divorcio y la responsabilidad civil", Revista de Derecho de Familia, 2014, No 3, pp. 139 ss.

Vargas Aravena, David, "Del Resarcimiento en Chile de los daños causados en el matrimonio", Revista Ius et Praxis (Universidad de Talca), 2015, Año 21, $N^{\circ} 1$, pp. 57-100.

Vidal Olivares, Álvaro, "La noción de menoscabo en la compensación económica por ruptura matrimonial”, Revista de Derecho P. Universidad Católica de Valparaíso, 2008, Vol. XXXI (2do sem.), pp. 289-321. 